\title{
Self-Portrait with Language Writing
}

Debates about identity and writing were something like mother's milk.

But, no. It wasn't the debates per se, which I had only an approximate grasp of at the time and which I continue to find productively unresolved, so that I flinch and bristle at attempts to settle matters authoritatively, whether in the service of the tragic part or the utopian whole. No, it was my experience of the writing projects of my peers that were thrilling and formative, the passionate explorations beyond the old scripts.

\section{ABC, OF WRITING}

A few years after I received an MFA from the Writers' Workshop in 1970 I found myself immersed in a very active scene in San Francisco with connections to New York City, Washington, and Toronto. Living was cheap, most of us were underemployed and didn't have kids. It felt as if we were writing all the time, writing and reading, and talking about it. "Writing" meant any model from literary history that winged in via someone's enthusiasm, as well as the activity called forth by the current piece of paper in the typewriter (these were the times of archaic media). We kept finding forms, tones, procedures, vocabularies that I'd not heard used before. We were not, to reverse Mauberley's words, "resuscitating the dead art of poetry"-quite the opposite. We felt we were continually reinventing a live art, which we called writing.

Now, this is true. But it's all too pleasant. Learning to trust invention in an environment of sustained, ambitious, cordial inventiveness - that's an inspiring set-up without much of a down side, is it not? There were rending struggles on behalf of racial justice and feminism, there was the War, pressing on every moment with greater or lesser conscious sharpness. Though the connections between these pressures and the polemics against the poetic self were very complex, they were often asserted with impatient simplification and were a major source of writing energy. 
But I do want to emphasize the exhilaration of living in a series of unpredictable writing experiences and offer that exhilaration as an antidote to the received idea of Language Writing as a theorydriven mortification of poetry. This notion still circulates widely. In a recent interview Michael Palmer - who at times is labeled as a Language Writer himself-says this about Language Writing:

My own hesitancy comes when you try to create, let's say, a fixed theoretical matrix and begin to work from an ideology of prohibitions about expressivity and the selfthere I depart quite dramatically from a few of the $\mathrm{L}=\mathrm{A}=\mathrm{N}=\mathrm{G}=\mathrm{U}=\mathrm{A}=\mathrm{G}=\mathrm{E}$ poets... my response is that if you're being told what not to do you turn around and do it - it's what the poem is there for, after all.

\section{SAVOIR-FAIRE}

I admire Michael's poems, and I agree that the poem can be a place to break rules. But that scenario presupposes an earlier scenario in which the rules had been presented emphatically, otherwise the prospect of negation would not be evident. My primordial memories of instruction suggest a different prospect. It was never particularly clear to me what the rules of poetry were. In this scenario, where convention and one's identity as a writer are both opaque matters, it is a relief to stumble upon the possibility that, in writing, you can find out something to do.

\section{SPEAKING OF DISIDENTIFICATION}

My "An Autobiography" begins:

Everyone keeps shouting in my ears. But rest assured, dear papa, that these are my very own sentiments and have not been borrowed from anyone.

Has the reader ever been madly in love? One does not load up on odds \& ends on the chance of their proving useful. The utmost reduction compatible with efficiency is the first \& last thing to aim at.

But I am putting off for too long a necessary statement. My mother was a charming woman and I was in love with her. One night, when by chance I had been put 
to sleep on the floor of her room on a mattress, this woman, agile as a deer, bounded over my mattress to reach her bed more quickly.

Why did I feel close to these words scrambled together out of the letters of Mozart's family, Shackleton's Antarctic journals, and Stendhal's autobiography, The Life of Henri Brulard? While they come from outside, they are not so much phrases "shouted in my ear" as false, intimate clues eagerly seized upon. I had begun to dip my toe in what could be called "theory." Some of my close friends were passionately emphatic about, for instance, Shklovsky and the Russian Formalists, who wrote of "laying bare the device." The opening sentences-Mozart's, from two different letters, I think - lay bare the device. But what "the device" then allows for is an undetermined complex of identification and disidentification. Masquerade can be a way to get to the party; masks worn at rakish angles can signal intimacy.

Another way to put it is that I was self-interpellating myself. I chose these sentences, by which I mean they chose me, captured me. Althusser's classic example is the cop saying "Hey, you!" to the pedestrian who is then constituted, "personized" I might say, from the outside, at that moment, by that call. In Althusser's scenario, however, the sense of guilt and powerlessness is overwhelming; the theorist, the one who can name "interpellation," is the only one who can gainsay it. But if in "An Autobiography" I was the juxtaposer of these capturing sentences, then I was less cop than midwife, arranging them so that they could haul out a performance of self that not only was unknown to me beforehand, but that had not existed beforehand. It was called into being by them. Should I say "I was called into being by them"? No, I shouldn't say "I" because this writing event was a certain kind of truth serum, lie serum, emotional experiment, libidinal x-ray for which the ubiquitousness and obviousness of the word "I" does little justice. Stendhal, Mozart, Shackleton, c'est moi. I, c'est pas moi.

\section{THEORY AND ITS DISSED CONTENTS}

I have used a few modernist, theoretical terms: laying bare the device, fetish, interpellation. In each case my use has been rather eccentric. In their correct usage all three are in the service of 
demystification: interpellation I've just discussed; laying bare the device implies an earlier state where a spectator-reader has been taken in by the drapery, scenery, clothing that had covered the device; and if the fetish is a site of psychic disavowal, an objective observer is required to designate it as a fetish. Hostility to theory springs from this divide: on the one side, the demystifiers with their mystifying terminologies; on the other, those labeled as mystified who then have a problem with the demystification since what they thought they knew as their experience is taken away and labeled as mystification.

My models seem to have involved critique and a simultaneous invitation to emotional bonding. I don't want to claim that this is exemplary of Language Writing; nor do I want to claim this is exemplary of myself. The fact that every poet is a person doesn't dissolve the communities, blocs, clubs, coteries of poetic production nor does it do away with the overcrowded name-sites of literary history. Neither a person nor a poetic movement will ultimately serve as a master term.

Marjorie Perloff begins a recent essay, "Language Poetry and the Lyric Subject: Ron Silliman's Albany and Susan Howe's Buffalo," by declaring that "the cardinal principle- of American Language poetics...has been the dismissal of "voice,"' a dismissal she connects with "the larger post-structuralist critique of authorship and the humanist subject." Her point is to undo the received idea that reads Language Writing solely through theory and opposes selfdestroying, subjectless Language Writing to lyric self-expression. She does this via close readings of Ron Silliman, Susan Howe, Leslie Scalapino, Barrett Watten, and Michael Palmer to make the point that each writer's "signature," to cite her term of choice, is highly individual.

I hope it is clear that I agree with her attack on this received idea of Language Writing. But I suppose it is also all too clear that my own "signature" is something that I cannot recognize in objectified form-just as I always recoiled from the Workshop advice I received in my novicehood to "find my voice."

This unease brings me to the title, "Self-Portrait with Language Writing." The force of that "with" attracted me because I can read it as saying three things: 1) "I am in solidarity with Language Writing"; 2) "I am constructing this self-portrait by using 
Language Writing"; 3) "This is a self-portrait in which the subject is posed with some other thing, in this case Language Writing." Since the writing here is normative sentences, with perhaps some odd juxtapositions on the larger scale between sections, sense 2 allows me to define an iconoclastic movement iconoclastically. It's

84 a brittle irony perhaps; but the issue is one I'll go forward with. Sense 3 animates my poem, "Confession," which begins,

Aliens have inhabited my aesthetics for decades. Really since the early 70 .

Before that I pretty much wrote as myself, though young. But something

has happened to my memory, my judgment: apparently, my will has been

affected. That old stuff, the fork in my head, first home run,

Dad falling out of the carI remember the words, but I

can't get back there anymore. I think they must be screening my

sensations. I'm sure my categories have been messed with....

"Confession" is a Workshop-esque title. Why? Am I simply trying to fly by as many nets as I manage to perceive? "You won't catch me, Language Writing; you won't catch me, Workshop; you won't catch me, Self with your actual memories!"

This well-known passage from Barthes's "The Death of the Author" seems to have defined my procedure in "An Autobiography" quite closely, even though I hadn't read it at the time: "We know now that a text is not a line of words releasing a single 'theological' meaning (the message of the Author-God).... The text is a tissue of quotations... [The writer's] only power is to 
mix writings, to counter the ones with the others." Four cataclysmic events are designated here, in paired sets: the Author dies, as does his now superceded counterpart, the Critic. Two new players come on the scene: the Writer, who lives or at least occupies the subject position of literary production, and the Writer's counterpart, the Barthesian Reader who "is without history, biography, psychology; he is simply that someone who holds together in a single field all the traces by which the written text is constituted." Ron Silliman comments shrewdly here that "the idealized, absent author of the New Critical canon has here been replaced by an equally idealized, absent reader."

But Silliman then goes on to identify the university as the site of this idealization and stasis: "while postmodernism in the arts has been conducted largely, although not exclusively, outside of the academy, the postmodern debate has been largely conducted between different schools of professors who agree only that they too dislike it." "Once incorporated into an institutional canon, the text becomes little more than a ventriloquist's dummy through which a babel of critical voices contend." "Because history, biography, and psychology [the qualities, remember, that the Barthesian Reader was said not to have] can only be real...there can be no single way to proceed in either the poem or the reading: the path between any two people can only be specific. By inserting their own presence into the text while aggressively denying those of author and reader alike, the ventriloquists of canonization have powerfully, often malevolently, shaped the terrain of choices available."

\section{MORE POLEMICS}

The polemic insistence of Silliman's prose is hard to miss, especially for me, since besides being a close friend of his for a quarter of a century, I've also been a target of his attack on academia. During a panel on The Marginalization of Poetry, my book on Language Writing, Silliman said that the book was deformed because it was written to get tenure, and he likened my situation to that of Oscar Schindler. I may "help a few bright students," but the cost is extreme. As a poet working in academia, I "actively participate in a process that will make it harder for people to ever read or write poetry in any intelligent fashion."

Here is part of my answer: 
The future comes from partial, conflicted poems, literary movements, presents. [Using] the word "academic" as a putdown...short-circuits a tension that can be productive. I don't want to be misunderstood here: much of the best current writing and some of the most interesting critical venues are situated outside the university.... But how far outside is one question. Many people who attended the original panel had their desire for poetry at least partially piqued in school. To dismiss academia as irremediable comes pretty close to perpetuating the old anti-intellectual stereotypes that made the notion of "creative writing" such a provincial totality a few decades back.... Can real poetry *only* exist in autonomous margins? But come on, if you're going to demonize universities - where are these other, valid workplaces? Is the page utopia upon which the true and beautiful opacity of the autonomous untranslatable poem lies, forever young, forever other, forever here? Fetish City!

Where did our passion for poetry come from? The page? Created by purely visual epiphany in a kind of unpedagogic, virgin birth?...pedagogy, repetition, and circulation are very widespread structuring conditions.... We all started somewhere well behind the starting line.

\section{SONG, OF MYSELF}

I recently got a glimpse back into my first enthusiasm for poetry, which came from reading Whitman as a young teen in high school. Some twenty-somethings staged a version of "Song of Myself": a seedy protagonist, part-bum, part-ghost strolled and skittered like a tormented schizophrenic dandy through the alleys of Old City in the lower reaches of central Philly near the Delaware River, while a guide carried along a boom box playing chunks of the poem. These taped recitations were supplemented by young people poised along our route in 19th-Century costume who would recite when our guide's flashlight lit them up. At first I was impatiently critical: the protagonist's worried look and franticness seemed a misreading. But the poem won me over. Walking through these narrow old alleys in an audience of twenty-five was a wonderful way to hear Whitman. The event was part of the Philly Fringe Festival and we had each paid our fifteen niche-market art-dollars, 
but still I had the palpable sense that the words of the poem were spoken in public space, which seemed like the apt setting for their eloquent expansions. The steady noise of cars heading toward Camden cascaded down from the Interstate as we walked by old brick row houses and warehouses, at one point coming close to the huge undergirdings of the Ben Franklin - not the WhitmanBridge and occasionally getting oddly angled vistas of a billboard displaying its eighty-foot intimate normative demand on the public libido. The passages of "Song of Myself" sounded wonderful as they spoke to this urban landscape. The gloomy brick buildings and the narrow cobbled streets had been there before Whitman was born. He had probably walked these alleys and seen these buildings minus a century's grime. The streetlights, freeway, bridge, billboards, the occasional cell phones of the restaurantgoers were new, but they had in some way been prophesied by the poem, which was beautiful, bizarre, unpredictable, shining a visionary and eminently pragmatic light onto Philly, not an easy thing to do.

I intended to quote some of what I heard, but in fact what I heard turns out to be a psycho-acoustic moment where my imagination, cathexis, memory, and refracted projection all took a hand in stirring the pot so that there was no re-recordable surface. In other words, what I heard wasn't all exactly in the book.

Why am I pursuing this inaccurate memory? To retail one's impressions rather than the poem itself is exactly wrong, it is the essential mechanism by which entropy pulls newly differentiated creation back to the polished debris of the familiar. I can hear the frustration in Jerome McGann's voice as he complained that students can't read poetry on the page, that they "pre-read." Every poet, critic, teacher would agree that the specific words of any writing are the absolute bedrock.

But what I'm trying to articulate here is that there is a dimension of desire below this. For Whitman, the "flag of his disposition" was grass growing from graves. I want to descry the flag of my disposition.

\section{ORDINARY LANGUAGE WRITING}

We are not in a binary battle between the Moderns and the Ancients; nor are we in a liberal playground where knee-jerk tol- 
erance is the primary virtue. Where then are we? Here is one of my answers:

Person, narrative, syntax, theatricality: the case against these has become foundational for antifoundational writing. But these can be a source of social-and hence poetic-effect. Every aspect of poetry is saturated with social thinking. The new emerges from the familiar. The emergence need not be coercive or bland. The poet acts in arenas of prior agreement: words, speech genres, rhythms that touch groups, classes. Disruptive gestures, if they ignore these agreements too autocratically, are easy to sweep into preexisting poetry corners.

I have heard paradise within words and I have read utopia in language. To many, paradise and utopia are idealist, or at least evanescent, unavailable, displaced into future or past by the blare and drone of ideology coating all our words and their couplings, sunderings, rearrangements. But both perfections lie within language and can be grasped, can be specified. They are historical geographies, inhabited by speakers and writers. Traffic signs, quite like ours, are in use there, though they are not always obeyed. Cars drive down roads, transforming fuel to smoke. Territories are fenced, and the boundaries are in dispute. Reports of paradise being inhabited by a single naked couple or utopia by a rapt individual or communal consciousness are delusive. They have newspapers there, weather, sports and propaganda. It is quite crowded, overcrowded in fact. There are huge populations; the numbers are stuporous. Fantastic masses, liberal and fanatic, starving and indolent, make an environment that is overwhelmingly present. Restaurateurs momentarily tangled in barbed wire strung along political boundaries are kicked to death because of their accent or their grandparents' accent. Lessons in violence, waste, systematic consequence and systematic chaos abound. Desire reflects and refracts endlessly, welling up in each locally wedged person, making walls which are often quickly shared, walls and malls, toll roads, cities, airports; the plastic pos- 
sibilities seem endless, though in all cases they are utterly enlaced in properties of matter: iron can float, cotton can kill. Language there is a shortcut to the infinite, often forming slogans in reaction, and forming social bonds strong beyond belief.

So.

A neutral observer, some phantasm of objectivity, might ask in conclusion, "If this is what you're saying, why the title? Why the junction of Ordinary Language and Language Writing? Isn't that just an oxymoron? Why keep that association? This piece doesn't seem to be Language Writing, in any 'ordinary' sense; nor do you seem to be a Language Writer, except by historical categorization. Or do you want to say that Language Writing is simultaneously utopian and social, and that this is the crucial point; that defamiliarization or comprehensibility or near-comprehensibility are just techniques, and not, by themselves, ethical or political commitments?"

I couldn't have said it better myself. 